\title{
Carbon-14 in Sagebrush on the Hanford Site and Vicinity
}

\author{
K. R. Price
}

July 1981

Prepared for the U.S. Department of Energy under Contract DE-AC06-76RLO 1830

Pacific Northwest Laboratory Operated for the U.S. Department of Energy by Battelle Memorial Institute 


\title{
NOTICE
}

This report was prepared as an account of work sponsored by the United States Government. Neither the United States nor the Department of Energy, nor any of their employees, nor any of their contractors, subcontractors, or their employees, makes any warranty, express or implied, or assumes any legal liability or responsibility for the accuracy, completeness or usefulness of any information, apparatus, product or process disclosed, or represents that its use would not infringe privately owned rights.

The views, opinions and conclusions contained in this report are those of the contractor and do not necessarily represent those of the United States Government or the United States Department of Energy.

\author{
PACIFIC NORTHWEST LABORATORY \\ operated by \\ BATTELLE \\ for the \\ UNITED STATES DEPARTMENT OF ENERGY \\ Under Contract DE-AC06-76RLO 1830
}

\author{
Printed in the United States of America \\ Available from \\ National Technical Information Service \\ Uniled States Department of Commerce \\ 5285 Port Royal Road \\ Springfield, Virginia 22151
}

Price: Printed Copy $\$$

$\because$ Microfiche $\$ 3.00$

\begin{tabular}{cc}
\hline Pages & $\begin{array}{c}\text { NTIS } \\
\text { Selling Price }\end{array}$ \\
\hline $001-025$ & $\$ 4.00$ \\
$026-050$ & $\$ 4.50$ \\
$051-075$ & $\$ 5.25$ \\
$076-100$ & $\$ 6.00$ \\
$101-125$ & $\$ 6.50$ \\
\hline $126-150$ & $\$ 7.25$ \\
$151-175$ & $\$ 8.00$ \\
$176-200$ & $\$ 9.00$ \\
$201-225$ & $\$ 9.25$ \\
\hline $226-250$ & $\$ 9.50$ \\
\hline $251-275$ & $\$ 10.75$ \\
$276-300$ & $\$ 11.00$ \\
\hline
\end{tabular}


CARBON-14 IN SAGEBRUSH ON THE HANFORD SITE AND VICINITY

K. R. Price

Ju1y 1981

Prepared for the

U. S. Department of Energy

under Contract DE-AC06-76RLO 1830

Pacific Northwest Laboratory

Richland, Washington 99352 


\section{SUMMARY}

The purpose of this study was to estimate the levels of ${ }^{14} \mathrm{C}$ in sagebrush wood from plants growing on the Hanford Site and vicinity and to determine if these levels could be attributed to past and present operations at Hanf ord.

Mature sagebrush plants were collected at one onsite and two offsite locations and analyzed for ${ }^{14} \mathrm{C}$. The offsite samples were collected both $60 \mathrm{~km}$ upwind and $26 \mathrm{~km}$ downwind from fuel reprocessing facilities on the Hanford Site. The results from these samples showed no statistically significant increased levels of ${ }^{14} \mathrm{C}$ for any time period during the operation of Hanford fuel reprocessing facilities. However, samples representative of the postnuclear era showed a $30 \%$ increase in ${ }^{14} \mathrm{C}$ content over prenuclear era (pre-1944) samples. This increase is primarily attributable to worldwide fallout resulting from atmospheric testing of nuclear weapons.

An important finding of the study was the approximate fourfold increase in ${ }^{14} \mathrm{C}$ detected in sagebrush wood collected onsite near the PUREX fuel reprocessing facility at Hanford. This result implies that sagebrush plants growing within $0.5 \mathrm{~km}$ of PUREX while the facility was in operation were exposed to an estimated average air concentration four times norma 1 or about $4 \mathrm{pCi} / \mathrm{m}^{3}$. This was during those times when the sagebrush was actively growing and assimilating carbon. The data indicate that sagebrush wood provides an historical record of changes in ${ }^{14} \mathrm{C}$ assimilation and, thus, some basis for judging what to expect in the way of increased levels of ${ }^{14} \mathrm{C}$ in vegetation following the proposed restart of PUREX operations. 
CONTENTS

$\begin{array}{lllllllllllllll}\text { SUMMARY } & \cdot & \cdot & \cdot & \cdot & \cdot & \cdot & \cdot & \cdot & \cdot & \cdot & \cdot & \cdot & i i \\ \text { INTRODUCTION } & \cdot & \cdot & \cdot & \cdot & \cdot & \cdot & \cdot & \cdot & \cdot & \cdot & \cdot & \cdot & 1 \\ \text { METHODS } & \cdot & \cdot & \cdot & \cdot & \cdot & \cdot & \cdot & \cdot & \cdot & \cdot & \cdot & \cdot & 3 \\ \text { RESULTS AND DISCUSSION } & \cdot & \cdot & \cdot & \cdot & \cdot & \cdot & \cdot & \cdot & \cdot & \cdot & 5 \\ \text { CONCLUSIONS } & \cdot & \cdot & \cdot & \cdot & \cdot & \cdot & \cdot & \cdot & \cdot & \cdot & \cdot & \cdot & 8 \\ \text { REFERENCES } & \cdot & \cdot & \cdot & \cdot & \cdot & \cdot & \cdot & \cdot & \cdot & \cdot & \cdot & \cdot & 9\end{array}$


CARBON-14 IN SAGEBRUSH ON THE

HANFORD SITE AND VICINITY

\section{INTRODUCTION}

In a continuing effort to assess the environmental impact of operations at the Hanford Site, this report sumarizes the results from a special study investigating the content of ${ }^{14} \mathrm{C}$ in local vegetation. The purpose of the study was to estimate the levels of ${ }^{14} \mathrm{C}$ in perennial vegetation, growing on the Hanford Site and nearby areas, that may have been attributable to present and past operations at Hanford. Results would be especially relevant to the proposed restart of the PUREX fuel reprocessing facility at Hanford. The PUREX facility is known to have released some ${ }^{14} \mathrm{C}$ to the atmosphere during past operations, but the resulting incorporation into vegetation was undefined. Data from the results of this study can be used as reference values indicative of the expected impact from future operations at the PUREX faciliy.

The general technique involved collecting samples of sagebrush (Artemisia tridentata), excising pieces of wood that represented various periods of time in the past, and analyzing the samples for ${ }^{14} \mathrm{C}$. The principal assumptions were that gaseous ${ }^{14} \mathrm{C}$ in the air around the sagebrush $\mathrm{plants}$ would have been incorporated into the woody tissue through normal processes and that the ${ }^{14} \mathrm{C}$ has remained there over the years.

Carbon-14 is a naturally occurring radionuclide with a half-life of 5730 years that is produced primarily from neutron-induced reactions with ${ }^{14} \mathrm{~N}$ in the upper atmosphere. Artificial production of ${ }^{14} \mathrm{C}$ began in the early 1940s with the advent of the nuclear era. Atmospheric testing of nuclear weapons produced significant quantities of ${ }^{14} \mathrm{C}$ from neutron reactions with ${ }^{14} \mathrm{~N}$ in the atmosphere and from nuclear fission of ${ }^{235} \mathrm{U}$ and ${ }^{239} \mathrm{Pu}$. Since the ban on atmospheric testing in 1962, nuclear reactors and fue 1 reprocessing facili-ties have been the major sources of ${ }^{14} \mathrm{C}$ production and subsequent release to the atmosphere. Neutron-induced reactions with ${ }^{14} \mathrm{~N},{ }^{17} \mathrm{O}$, and ${ }^{13} \mathrm{C}$ and nuclear fission of ${ }^{235} \mathrm{U}$ and ${ }^{239} \mathrm{Pu}$ are important 
production mechanisms. The ${ }^{14} \mathrm{~N}(\mathrm{n}, \mathrm{p}){ }^{14} \mathrm{C}$ reaction is the most important because of the great abundance and large nuclear cross-section of ${ }^{14} \mathrm{~N}$ (Hayes and MacMurdo 1977). Nitrogen-14 occurs as an impurity in nuclear fue 1 and is converted to ${ }^{14} \mathrm{C}$. Virtually all ${ }^{14} \mathrm{C}$ contained in the irradiated fue 1 may be released as a gas mixture $\left(\mathrm{CO}_{2}, \mathrm{CO}, \mathrm{CH}_{4}\right.$, etc.) during fue 1 dissolution at a reprocessing $\mathrm{pl}$ ant un 1 ess special preventative measures are taken (Davis 1977).

Murphy and Dixon (1977) described their modeling effort that pointed out the importance of correlations between dispersion climatology and patterns of $\mathrm{plant}$ growth processes when predicting the assimilation of a pollutant by vegetation. Their results show that vegetation can assimilate more ${ }^{14} \mathrm{C}$ from a point source during daylight hours than at other times, due to $\mathrm{plant}$ photosynthesis and atmospheric instability associated with daylight hours.

Dendrochronology is the study of tree growth rings. It is we 11 known that ${ }^{14} \mathrm{C}$ can be incorporated into tree wood and that the ${ }^{14} \mathrm{C}$ content of each ring of wood represents the ambient concentration of ${ }^{14} \mathrm{C}$ in the atmosphere during the year the ring was produced. Damon, Long and Wallick (1972) studied the variation in natural ${ }^{14} \mathrm{C}$ in wood produced over a period of 7000 years and preserved in very old trees. 


\section{METHODS}

SAMPLE COLLECTION AND PREPARATION

Ten mature sagebrush plants were collected at each of three study sites. An upwind offsite location was at the Washington State Plant Introduction Station near Moxee, Washington (Yakima County), about $60 \mathrm{~km}$ west of the Hanford 200 Areas where fuel reprocessing facilities are located. A second offsite location was about $7 \mathrm{~km}$ south of Highway 240 on Horn Road near Benton City and about $26 \mathrm{~km}$ southeast and generally downwind of the Hanford 200 Areas. A third study site was about $0.5 \mathrm{~km}$ east of the PUREX fuel reprocessing facility's 90-m tall exhaust stack, which is located in $200 \mathrm{E}$ Area.

Selected sagebrush plants were severed at ground level and a section of the main stem returned to the laboratory. Cross-sections of stems (each $2.5 \mathrm{~cm}$ thick) were prepared with a band saw. A sharp knife was used to carefully separate groups of annual rings corresponding to the time periods to be studied. Separation between rings was noted to be clean and precise. Ten grams of dry wood were prepared for ${ }^{14} \mathrm{C}$ analysis.

\section{CARBON-14 ANALYSIS}

Carbon-14 analyses were conducted by the U.S. Testing Company, Inc. (UST) Richland, Washington, using a benzene synthesizer. (a) The complete procedure has been described in their procedure manual (UST 1980). The system utilizes a dry combustion chamber to oxidize the sample and produce $\mathrm{CO}_{2}$. The $\mathrm{CO}_{2}$ is converted to lithium carbide that is then reacted with water to produce acetylene. Benzene is synthesized from the acetylene, mixed with a scintillator fluid, and counted. An oxalic acid standard was used to relate results to the "modern" standard of $13.5 \mathrm{dpm}{ }^{14} \mathrm{C} / \mathrm{g}$ of carbon established for prenuclear carbon (Fairhall and Young 1970). For the purpose of relating ${ }^{14} \mathrm{C}$ data to nonradioactive carbon, the mean loss-on-ignition carbon content of sagebrush wood was determined to be $57.1 \%$ (C.V. $=0.3 \%, n=9$ ) on a dry weight basis.

(a) The instrument was purchased from TASK, Inc, Oak Ridge, TN. 
SAMPLING PERIODS

Preliminary results obtained from a few samples collected in 1978 indicated that the ${ }^{14} \mathrm{C}$ content of sagebrush wood was highly variable, especially for samples collected near the PUREX facility. To help compensate for this variability, the number of plants sampled in 1979 was increased to ten. The observed variability may not have been caused by the manner in which ${ }^{14} \mathrm{C}$ was assimilated by sagebrush plants but rather by the imprecise identification of individual annual growth rings. This lack of precise identification would be amplified by the longer the sample period and, thus, the more rings that needed to be counted. Therefore, a "buffer layer" of one or two years of wood was removed on either side of a critical date during sample preparation. For example, the PUREX facility ceased operation in September 1972, but wood specimens representing the postoperational period were prepared to consist of annual rings formed in the period 1974 through 1979, instead of 1973 through 1979. Similarly, the sample representing the period of PUREX operation ended in 1970 instead of 1972.

Time periods chosen for study were based on the location of the study site and the periods of operation at Hanford as indicated in Table 1.

TABLE 1. Sample Locations and Sampling Time Periods

\begin{tabular}{|c|c|}
\hline Location & Time Period \\
\hline Al1 sites listed & Pre-1944 - pre-Hanford operations \\
\hline Moxee, Washington & 1944-1978 - during all Hanford operations \\
\hline Benton City, Washington & $\begin{array}{l}1944-1972 \text { - during Hanford operations with fue } 1 \\
\text { reprocessing }\end{array}$ \\
\hline Benton City, Washington & $\begin{array}{l}\text { 1973-1978 - during Hanford operations without } \\
\text { fuel reprocessing }\end{array}$ \\
\hline Hanford, Washington & $\begin{array}{l}1946-1955 \text { - during Hanford operations REDOX fue } 1 \\
\text { reprocessing (a) }\end{array}$ \\
\hline Hanford, Washington & $\begin{array}{l}1956-1972 \text { - during Hanford operations PUREX fue } 1 \\
\text { reprocessing }(\mathrm{a})\end{array}$ \\
\hline Hanford, Washington & $\begin{array}{l}1973-1979 \text { - during Hanford operations without } \\
\text { fuel reprocessing }\end{array}$ \\
\hline
\end{tabular}

(a) The REDOX (200W Area) and PUREX (200E Area) facilities have been the principal fuel reprocessing plants at Hanford. 


\section{RESULTS AND DISCUSSION}

Table 2 shows the results in $\mathrm{dpm}{ }^{14} \mathrm{C} / \mathrm{g}$ of carbon for the time periods indicated. A t-test was used to test for significant differences between means. Of the many comparisons possible, only three were significantly different $(\alpha \leq 0.01)$ :

- Moxee pre-1944 was less than Moxee 1944-1978

- Benton City pre-1944 was less than either Benton City 1944-1972 or Benton City 1974-1978

- Hanford 1956-1972 samples contained greater quantities of ${ }^{14} \mathrm{C}$ than any other sample period or location.

The overall sample average for the pre-Hanford period was $13.4 \mathrm{dpm}{ }^{14} \mathrm{C} / \mathrm{g}$ of carbon (C.V. $=12 \%$ ), a value essentially identical to the published value of 13.5 for "modern," prenuclear era carbon (Fairha11 and Young 1970). There was no statistical difference between Hanford and either of the offsite locations for the time periods when the PIJREX facility was not operating. Moreover, the average value for all offsite samples representing the time period during Hanford operations (i.e., the postnuclear era) was $17.5 \mathrm{dpm}{ }^{14} \mathrm{C} / \mathrm{g}$ of carbon (C.V. $=12 \%$ ), which is $130 \%$ of the "modern" value of $13.5 \mathrm{dpm}{ }^{14} \mathrm{C} / \mathrm{g}$ of carbon. A $130 \%$ to $145 \%$ enhancement in ${ }^{14} \mathrm{C}$ since the $1960 \mathrm{~s}$ is global in nature and is primarily the result of the atmospheric testing of nuclear weapons. Thus, it does not appear that fue 1 reprocessing (or reactor operations) at Hanford significantly influenced the ${ }^{14} \mathrm{C}$ content of the samples collected at either of the two offsite locations.

It should be noted that a coal-fired steam boiler was located $1.4 \mathrm{~km}$ west (upwind) of the PUREX facility. The $\mathrm{CO}_{2}$ produced from burning coal is low in ${ }^{14} \mathrm{C}$ and may have contributed to the variability noted in some of the Hanford samples, especially Hanford 1946-1955. The phenomenon is known as the Suess effect (Suess 1955). 


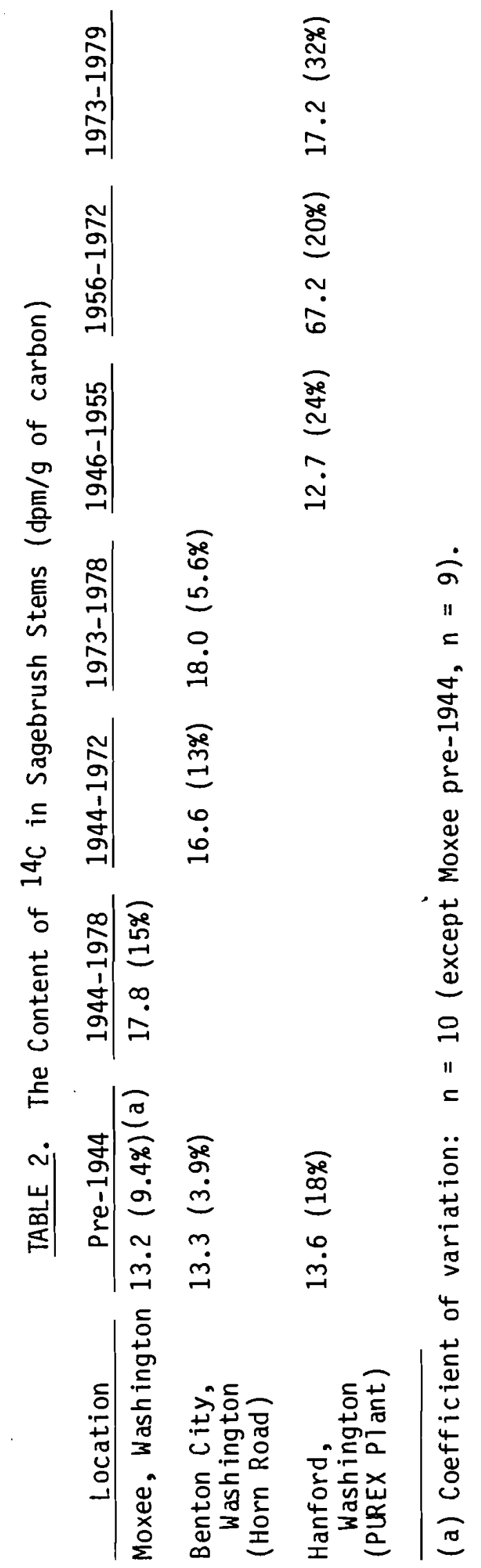


The important finding of this investigation was the approximate fourfold increase in ${ }^{14} \mathrm{C}$ detected in sagebrush wood collected near the PUREX fue 1 reprocessing facility, representative of the time period of facility operation (Table 2). However, in a manner cautioned by Murphy and Dixon (1977), this value $\left(67.2 \mathrm{dpm}{ }^{14} \mathrm{C} / \mathrm{g}\right.$ of carbon) cannot be used to estimate the annual average air concentration of ${ }^{14} \mathrm{C}$ at the sampling site because carbon assimilation and atmospheric instability (which occur mostly during daylight hours) each influence the ${ }^{14} \mathrm{C}$ content of wood. These processes tend to increase the ${ }^{14} \mathrm{C}$ content of wood because absorption by vegetation occurs preferentially during daylight hours (i.e., during photosynthesis) when air concentrations near vegetation may be temporarily increased due to plume looping toward the ground surface in response to atmospheric instability. An additional complicating factor for arid climates is that sagebrush actively grows only when sufficient soil moisture is present, presumably from October through April, and especially in the spring months when temperatures also are favorable. The Hanford sample plants (1956-1972) were exposed over a period of 13 years to an average air concentration of about $4 \mathrm{pCi}{ }^{14} \mathrm{C} / \mathrm{m}^{3}$, (a) during those times when the $\mathrm{plants}$ were actively growing and assimilating carbon.

The data indicate that sagebrush wood provides an historical record of changes in ${ }^{14} \mathrm{C}$ assimilation and some basis for judging what to expect in the way of increased levels of ${ }^{14} \mathrm{C}$ in vegetation following the proposed restart of PUREX operations. A nondestructive biological monitoring of ${ }^{14} \mathrm{C}$ could be carried out by collecting samples of the annual leaf fall from sagebrush plants growing at several locations on the Hanford Site.

(a) Assuming $177 \mathrm{mg} \mathrm{C} / \mathrm{m}^{3}$ air (STP;0.0\% R.H.). 
The purpose of this study was to estimate the levels of ${ }^{14} \mathrm{C}$ in sagebrush stems growing onsite and offsite of the Hanford Project and to determine what influence, if any, the production and release of ${ }^{14} \mathrm{C}$ from Hanford facilities had on the ${ }^{14} \mathrm{C}$ content of vegetation. Samples collected $60 \mathrm{~km}$ away in a general upwind direction, as we 11 as those collected $26 \mathrm{~km}$ away in a general downwind direction from fuel reprocessing facilities, showed no statistically significant increase in levels of ${ }^{14} \mathrm{C}$ for any time period during the operation of Hanford facilities. Offsite samples representing growth during the nuclear era (1945 to present) did reflect a $30 \%$ increase in ${ }^{14} \mathrm{C}$ concentration per gram of carbon compared to samples representing the prenuclear era. This enhancement in ${ }^{14} \mathrm{C}$ in biological materials is global in nature and is due primarily to the testing of nuclear weapons in the atmosphere. The principal feature of results from this study was the nearly fourfold increase in ${ }^{14} \mathrm{C}$ concentration in sagebrush wood produced by $\mathrm{plants}$ growing near the PUREX facility during fuel reprocessing operations in past years.

Under steady state conditions, the ${ }^{14} \mathrm{C}$ concentration in the air surrounding a plant will be equivalent to the ${ }^{14} \mathrm{C}$ concentration in woody tissue produced by the plant. However, the same cannot be said for the case of a point source resulting in an artificial increase in atmospheric ${ }^{14} \mathrm{C}$. Plant assimilation of ${ }^{14} \mathrm{C}$ occurs preferentially during daylight hours when the atmosphere tends to be unstable, and woody tissue produced during these exposure conditions will have a higher than expected ${ }^{14} \mathrm{C}$ content. An offsetting feature associated with arid climates is that sagebrush plants actively grow only for about seven months out of the year. Thus, the average air concentration at the Hanford study site over a 13-year period during those times, when sagebrush plants were actively growing and assimilating carbon, was four times normal or about $4 \mathrm{pCi}{ }^{14} \mathrm{C} / \mathrm{m}^{3}$.

The data indicate that sagebrush wood provides an historical record of changes in ${ }^{14} \mathrm{C}$ assimilation, and some basis for judging what to expect in the way of increased levels of ${ }^{14} \mathrm{C}$ in vegetation following the proposed restart of PUREX operations. 


\section{REFERENCES}

Damon, P. E., A. Long, and E. I. Wa1lick. 1972. "Dendrochronological Calibration of the Carbon-14 Time Scale." In Proceedings of 8th International Conference on Radiocarbon Dating, Vol. 1, p 45. Lower Hutt, New Zealand.

Dav is, W., Jr. 1977. Carbon-14 Production in Nuclear Reactors. ORNL/NUREG/TM-12, Union Carbide Corporation, Oak Ridge, Tennessee.

Fairhal1, A. W., and J. A. Young. 1970. "Radiocarbon in the Environment." Advances in Chemistry Series, 93:401-418.

Hayes, D. W., and K. W. MacMurdo. 1977. "Carbon-14 Production by the Nuclear Industry." Health Physics, 32:215-219.

Murphy, B. D., and K. R. Dixon. 1977. A Discrete Event Approach to Pollutant Transport and Vegetation Effects. ORNL/CSD/TM-11, Union Carbide Corporation, Oak Ridge, Tennessee.

Suess, H. E. 1955. "Radiocarbon Concentration in Modern Wood." Science, 122:415-417.

U.S. Testing Company, Inc. 1980. Procedure Manual. UST-RL-PM-9-80, U.S. Testing Company, Inc., Richland, Washington. 


\section{DISTRIBUTION}

No. of

Copies

OFFSITE

A. A. Churm

DOE Patent Division

9800 South Cass Avenue

Argonne, IL 60439

27 DOE Technical Information Center

\section{ONS ITE}

9 DOE Richland Operations Office

R. R. Austin

D. R. Elle (5)

H. E. Ransom

J. L. Rhoades

M. J. Zamorski

5 Rockwe 11 Hanford Operations

J. D. Anderson

W. M. Harty, Sr.

B. E. Knight

R. M. Mitche 11

D. L. Uh 1

1 Westinghouse Hanford Company

R. B. Ha 11

2 UNC Nuclear Industries, Inc.

P. A. Carlson

J. J. Dorian
No. of

Copies

31 Pacific Northwest Laboratory

P. E. Bramson (2)

J. P. Cor ley

J. J. Fuquay

H. V. Larson

K. R. Price (15)

W. H. Rick ard

M. J. Sula

B. E. Vaughan

Publ ishing Coordination (2)

Technical Information $\mathrm{CH}$ (5) 